\title{
Poglądy Klementyny z Tańskich Hoffmanowej 1798-1845 w refleksji uczennic. Zarys zagadnienia
}

The Ideas of Klementyna Nee Tańska Hoffmanowa (1798-1845) in the Reflection of Her Students. An Outline

\begin{abstract}
ABSTRAKT
Klementyna Hoffmanowa z domu Tańska (1798-1845) przez pięć lat (1826-1831 r.) pracowała jako nauczycielka „nauki moralnej” w Instytucie Rządowym Wychowania Płci Żeńskiej (Instytucie Guwernantek) oraz na zwiqzanej z nim Pensji Wzorowej. Do grona jej uczennic należała m.in. Seweryna Duchińska z domu Żochowska, $1^{\circ} \mathrm{v}$. Pruszakowa (1816-1905). Pruszakowa - poetka, publicystka, tłumaczka - wydawała pismo „Rozrywki dla Młodocianego Wieku”, gdzie zamieściła kilkudziesięciostronicowy życiorys Hoffmanowej (1856, t. 1-2). Wśród uczennic Tańskiej znalazła się również Teodozja Papi z domu Gałęzowska (1810-1887). Kilkanaście lat po jej śmierci na bazie wspomnień Teodozji jej córka, pisarka Jadwiga Papi (1843-1906) poświęciła Tańskiej jeden z rozdziałów powieści Klementyna. Powieść dla dorastajacych panien osnuta na tle życia Klementyny z Tańskich Hoffmanowei (1905). Jednak szczególna rola przypadła najbardziej znanej z uczennic
\end{abstract}

Articles and dissertations
SLOWA KLUCZE

Klementyna z Tańskich Hoffmanowa, Narcyza Żmichowska, kobiety, edukacja, program wychowania kobiet polskich, wiek XIX

\section{KEY WORDS}

Klementyna Hoffmanowa nee Tańska, Narcyza Żmichowska, women, education, education program of Polish women, nineteenth century

SPI Vol. 19, 2016/3 ISSN 2450-5358 e-ISSN 2450-5366 DOI: 10.12775/SPI.2016.3.005 Artykuły i rozprawy 
Klementyny z Tańskich Hoffmanowej, wspomnianej Narcyzie Żmichowskiej (1819-1876), autorce kontrowersyinego eseju Słowo przedwstępne do dzieł dydaktycznych Pani Hoffmanowei (1876).

Pozostawione przez uczennice Klementyny z Tańskich Hoffmanowej opinie i refleksje majq rozmaity charakter. Sq wśród nich tzw. "ego-dokumenty”, m.in. życiorysy/biografie (Pruszakowa), ale także artykuły, opracowania krytyczno-literackie (Żmichowska) oraz formy powieściowe (Papi).

\section{ABSTRACT}

Klementyna Hoffmanowa nee Tańska (1798-1845), worked as a teacher of "Moral Teaching" for five years (1826-1831). She was employed at the Government Institute of Female Education (Institute for Governesses) and the associated Model School for Girls. Her students included Seweryna Duchińska nee Żochowska 1 v Pruszakowa. (1816-1905). Pruszakowa - poet, journalist and translator edited the Rozrywki dla Młodocianego Wieku [Entertainment for the Young Age] magazine, where she published a few dozen page long biography of Hoffmanowa (1856, 1-2). Another student of Tańska was Teodozja Papi nee Gałęzowska (1810-1887). Several years after her death, based on the memories of her mother, Teodozja's daughter Jadwiga Papi (1843-1906) devoted one of the chapters of her novel Klementyna. Powieść dla dorastajqcych panien osnuta na tle życia Klementyny z Tańskich Hoffmanowej [Klementyna. A Novel for Adolescent Girls Based on the Life of Klementyna Hoffmanowa nee Tańska] (1905). However, a special role was played by the most famous student of Klementyna Tańska, namely, Narcyza Żmichowska (1819-1876), author of a controversial essay "Słowo przedwstępne do dzieł dydaktycznych Pani Hoffmanowej" ["Preliminary Commentary to the Work of Teaching of Mrs. Hoffmanowa"] (1876).

Opinions and reflections left by students of Klementyna Tańska-Hoffmanowa are varied. They include so-called "ego-documents", such as biographies (Pruszakowa), but also articles, critical-literary essays (Żmichowska) and novels (Papi).

\section{Wstęp}

Klementyna z Tańskich Hoffmanowa (1798-1845) „najruchliwsza i niemal jedyna $\mathrm{w}$ kraju w pierwszej połowie byłego wieku [tj. XIX - M.S.K.] poważniejsza działaczka na polu 


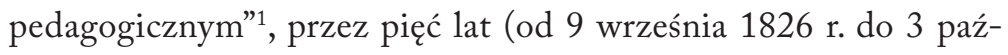
dziernika 1831 r.) pracowała jako nauczycielka "nauki moralnej” w Instytucie Rządowym Wychowania Płci Żeńskiej (popularnie nazywanym Instytutem Guwernantek) oraz na związanej z nim Pensji Wzorowej, dochowując się pokaźnego grona uczennic. Kilka spośród nich pozostawiło wspomnienia dotyczące dawnej nauczycielki. Owe refleksje mają rozmaity charakter; są wśród nich tzw. "ego-dokumenty", m.in. życiorysy/biografie ${ }^{2}$, artykuły, opracowania krytyczno-literackie oraz formy powieściowe. W niniejszym opracowaniu potraktowano je jako tzw. „literatura dokumentu osobistego" ${ }^{3}$. Cechą tego rodzaju dzieł, mocno naznaczonych autorskim „ja”, jest nie tylko subiektywizm narracji, ale często także i tendencyjność. Tę właściwość posiadają wszystkie wymienione utwory, które powstając $\mathrm{w}$ ściśle określonym celu zawierały odpowiednie przesłanie - apoteozę lub krytykę Hoffmanowej, jej programu edukacyjno-wychowawczego oraz propagowanego przez nią ideału kobiety polskiej, dostosowanego do czasów niewoli.

Do grona uczennic Klementyny z Tańskich Hoffmanowej należała m.in. Seweryna Duchińska z domu Żochowska $1^{\circ} \mathrm{v}$. Pruszakowa (1816-1905), przez dwa lata związana z pensją ${ }^{4}$. Pruszakowa - poetka, publicystka, tłumaczka - w drugiej połowie XIX wieku wydawała pismo „Rozrywki dla Młodocianego Wieku” (1856-1863), gdzie zamieściła obszerny życiorys swojej nauczycielki (1856, t. 1-2). Wśród uczennic Tańskiej była również Teodozja Papi z domu Gałęzowska (1810-1887), córka chorążego Tomasza Gałęzowskiego, która pobierała nauki na warszawskiej Pensji Wzorowej. Kilkanaście lat po

1 J. Nitowski, Klementyna z Tańskich Hoffmanowa, „Przegląd Pedagogiczny” 1898, nr 23, s. 405.

2 Ego-dokumenty, to m.in. wspomnienia, biografie, listy. Zob. W. Szulakiewicz, Ego-dokumenty i ich znaczenie w badaniach naukowych, „Przegląd Badań Edukacyjnych" 2013, nr 16, s. 67.

3 Zob. R. Zimand, Diarysta Stefan Ż., Wrocław 1990, s. 15. Zbigniew Jarosiński „literaturę dokumentu osobistego” opisał jako (1) „dokumenty” - „ponieważ mają charakter nie fikcyjny, przynoszą zapis jakiejś rzeczywistości, która istnieje realnie”, (2) „osobiste” - ,ponieważ «ja» piszące jest w nich to $\dot{z}^{-}$ same z konkretną osobą autora”; Z. Jarosiński, Proza dokumentu osobistego, w: Sporne postaci polskiej literatury wspótczesnej, red. A. Brodzka, L. Burska, Warszawa 1998, s. 325.

4 S. Pruszakowa [Duchińska), Rozrywki dla mtodocianego wieku, Warszawa 1956, t. 1-2. 
śmierci Teodozji Papi, na kanwie jej wspomnień, córka - Jadwiga Papi (1843-1906) poświęciła dawnej nauczycielce swojej matki powieść Klementyna. Powieść dla dorastajacych panien osnuta na tle życia Klementyny z Tañskich Hoffmanowej (1905)5. Szczególna rola przypadła jednak Narcyzie Żmichowskiej (1819-1876) pensji oraz Instytutu Guwernantek ${ }^{7}$ - późniejszej powieściopisarce, poetce, redaktorce i emancypantce -zdecydowanie najbardziej znanej ze wszystkich uczennic Klementyny z Tańskich Hoffmanowej. Pod wpływem profesora Ignacego Baranowskiego w połowie 1874 roku Żmichowska podjęła się opracowania jubileuszowego wydania zbiorowego Dziet Klementyny z Tańskich Hoffmanowej. Jako komentarz i swoisty „wstęp” do dziesięciotomowej edycji dzieł swojej nauczycielki, jej dawna uczennica napisała kontrowersyjne Stowo przedrustępne do dziet dydaktycznych Pani Hoffmanowej, panegiryczno-ironiczną rozprawę pełną autobiograficznych odniesień - błyskotliwą, dowcipną, sarkastyczną i w gruncie rzeczy nie do końca wiarygodną „Otrzymaliśmy stustronicowy esej krytycznym nie wiadomo do końca - pamflet czy panegiryk (...), papierowego konia trojańskiego, «balsam i truciznę»" - skonstatowała po latach Grażyna Borkowska ${ }^{10}$. W swoim Stowie przedrwstępnym do dziet dydaktycznych, obok przyznania Hoffmanowej niekwestionowanych zasług (takich jak:

5 J. Papi, Klementyna. Powieś́ dla dorastających panien osnuta na tle życia Klementyny z Tańskich Hoffmanowej, Warszawa-Kraków 1905. Papi była też autorką Gabrielli (1906) - powieści biograficznej o Narcyzie Żmichowskiej.

6 N. Żmichowska, Stowo przedwstęne do dziet dydaktycznych pani Hofmanowej, w: Dzieta Klementyny z Tańskich Hofmanowej, t. 8, Warszawa 1876.

7 W Instytucie Żmichowska uczyła się jednak dopiero po powstaniu listopadowym (1833-1835), kiedy Tańskiej już tam nie było.

8 W wielu ówczesnych kręgach Żmichowska była uznawana za „skandalistkę". Por. M. Woźniakiewicz-Dziadosz, Dzieje przyjaźni entuzjastek w świetle listów Narcyzy Żmichowskiej do Bibianny Moraczerwskiej, Annales Universitatis Mariae Curie-Skłodowska, Lublin - Polonia, vol. XX/XXI, sectio FF, 2002/2003 (UMCS LUBLIN), s. 2-3.

9 W tamtych czasach już Maria Ilnicka podawała w wątpliwość wiarygodność Żmichowskiej, pisząc o „dziwnym niezrozumieniu” przez nią swojej nauczycielki i o „fałszywym pojmowaniu wielu myśli" Hoffmanowej. Zob.M. Ilnicka, Narcyza Żmichorwska, „Bluszcz” 1877, nr 4-16.

10 G. Borkowska, Cudzoziemki. Studia o polskiej prozie kobiecej, Warszawa 1996, s. 59. Sympatie autorki wyraźnie sytuują się po stronie Żmichowskiej. Polemikę z Borkowską w obronie Hoffmanowej podjęła J. Dąbrowska. W artykule nawiązano do ustaleń badaczek. 
odegranie „ważnej roli w ukształtowaniu kobiet polskich”, wezwanie kobiet „do oświaty” oraz do „wznioślejszych obowiązków i cnót”, czy „zasług w propagowaniu języka polskiego"11), Żmichowska zawarła także bardzo krytyczne opinie podważające walory dydaktyczne jej utworów oraz negujące ideały wychowawcze propagowane przez dawną nauczycielkę ${ }^{12}$.

\section{Program wychowawczy Klementyny z Tańskich Hoffmanowej: ideał kobiety-Polki czasów zaborów}

Urodzona w tym samym roku co Adam Mickiewicz (1798), Klementyna z Tańskich Hoffmanowa należała do pokolenia nie znającego już wolnej Polski ${ }^{13}$. Ta wyrosła w szczególnej sytuacji historycznej generacja musiała szukać dla siebie nowych sposobów na życie ${ }^{14}$. Pierwsze pokolenie urodzone i wychowane w niewoli („pokolenie przełomu wieków") dotknęły bowiem wielowymiarowe przemiany społeczne, obyczajowe, kulturalne ${ }^{15}$. Po klęsce rozbiorów, wraz z którymi zniknęły także instytucje demokracji szlacheckiej (sejm, sejmiki) ${ }^{16}$, stopniowy rozkład dawnych struktur społecznych z czasem doprowadził do wykształcenia się nowej społecznej warstwy inteligencji, do której należała także i Tańska ${ }^{17}$. Przy tym, jak zauważył Kazimierz Wyka, było to „pierwsze pokolenie młodzieży, które

11 N. Żmichowska, Stowo przedwstępne do dziet dydaktycznych pani Hofmanowej, w: dz. cyt., s. 247, 296, 249.

12 Prawdopodobnie $\mathrm{z}$ tego względu wydawcy pism Hoffmanowej nie zamieścili rozprawy Żmichowskiej na początku edycji, ale „ukryli” ją w tomie ósmym Dziet. Zob. M. Romankówna, Narcyza Żmichowska (Gabriella), Kraków1970, s. 27.

13 Życiorys Klementyny z Tańskich Hofmanowej zob. Z. Ciechanowska, biogram: Hoffmanowa z Tańskich Klementyna (1798-1845), w: Polski Stownik Biograficzny, t. 9, 1961, s. 573-576.

14 T. Eepkowski, Polska - narodziny nowoczesnego narodu 1764-1870, Warszawa 1967.

15 Pokolenie to opisała A. Witkowska, Rówieśnicy Mickiewicza. Życiorys jednego pokolenia, Warszawa 1962.

16 S. Grodziski, Schytek stanu szlacheckiego na ziemiach polskich, w: Spoteczeństwo polskie XVIII i XIX wieku, t. VIII, red.J. Leskiewiczowa, Warszawa 1987, s. 99.

17 Zob. Dzieje inteligencji polskiej do roku 1918, red. J. Jedlicki, t. 1: M. Janowski, Narodziny inteligencji 1750-1831, Warszawa 2008, s. 11. 
w pełni korzystało z prac nad reformą wychowania, teraz dopiero, z chwilą upadku politycznego Polski, osiągających szerszy zakres"18.

Tańska była jedną z pierwszych Polek, które utrzymywały się dzięki własnej pracy. Ważnym źródłem jej utrzymania była działalność literacka. W roku 1825 Hoffmanowa była również wizytatorem honorowym dwóch warszawskich pensji i szkół żeńskich (pełniła funkcje „eforki” - Damy Dozoru $)^{19}$. Na początku roku 1828 została mianowana wizytatorem wszystkich szkół i pensji dla dziewcząt w Warszawie. Równocześnie wydawała i redagowała pierwsze polskie czasopismo przeznaczone dla dzieci, miesięcznik „Rozrywki dla Dzieci” (1824-1828) ${ }^{20}$. Chociaż sama Tańska prezentowała już nowy typ kobiety: wykształconej, interesującej się sprawami publicznymi, a przy tym głęboko religijnej i patriotycznej ${ }^{21}$, to jednak jej stanowisko odnośnie do kobiet $\mathrm{i}$ ich roli w społeczeństwie było jeszcze tradycyjne, autorka Pamiatki po dobrej matce uznawała bowiem podrzędną rolę kobiety w życiu publicznym oraz konieczność podporządkowania kobiety mężczyźnie. Przy tym jednak postulowała potrzebę kształcenia się kobiet i podejmowania (zwłaszcza przez te uboższe) pracy zarobkowej ${ }^{22}$.

Uczennice Klementyny z Tańskich Hoffmanowej należały już do innej generacji. Biologicznie należały do tego samego pokolenia

18 K. Wyka, Pokolenia literackie, Kraków 1977, s. 156.

19 Urząd i funkcję Dam Dozoru zaprojektowała Izba Edukacyjna w 1808 r. W roku 1810 Rada Dozorcza Dam opracowała i ogłosiła Regulament dla pensji i szkót ptci żenskiej, będący pierwszym dokumentem pracy polskich kobiet w dziedzinie prawodawczej. Zob. H.J. Rygier, Materiaty do dziejów órwiaty w Polsce. Dozór szkót żeńskich w Księstwie Warszawskim, Warszawa 1917, s. 5-6; A. Winiarz, Ksztatcenie i wychowanie dziewczat w Księstwie Warszawskim i Królestwie Polskim (1807-1905), w: Kobieta i edukacja na ziemiach polskich w XIX i XX wieku, red. A. Żarnowska i A. Szwarc, cz. 2, Warszawa 1995, s. 3-18.

20 P. Chmielowski, Klementyna z Tańskich Hofmanowa. Zarys biograficzno-pedagogiczny przez Piotra Chmielowskiego, dz. cyt., s. 11, 33.

21 J.E. Dąbrowska, Klementyna. Rzecz o Klementynie z Tańskich Hoffmanowej, Białystok 2008, s. 69; J. Gawlik, Dziedzictwo pedagogiczne Klementyny z Tańskich Hoffmanowej, Opole 1995, s. 38 i n

22 Chociaż w powieści Krystyna (1841), zawierającej elementy autobiograficzne, Hoffmanowa przedstawiła wizerunek tytułowej bohaterami, jako emancypantki, żyjącej na własny rachunek. Tak też, tj. „emancypantką” nazywała ją m.in. Deotyma. Określenie to miało jednak wówczas stosunkowo szerokie znaczenie. 
romantyków, co m.in.: Zygmunt Krasiński (ur. 1812), Józef Ignacy Kraszewski (ur. 1812), August Cieszkowski (ur. 1814), Edmund Wasilewski (ur. 1814), Ryszard Berwiński (ur. 1817), Gustaw Ehrenberg (ur. 1818). Generacja ta, urodzona po klęsce Napoleona, w okolicach Kongresu Wiedeńskiego (1815), posiadała już inne doświadczenia pokoleniowe: w dzieciństwie (lub w okresie młodzieńczym) przeżyła wydarzenia powstania listopadowego, zaś w wieku dojrzałym doświadczyła tragicznych skutków klęski powstania styczniowego oraz istotnych przemian społecznych, cywilizacyjnych i kulturowych ${ }^{23}$. $\mathrm{W}$ pokoleniu tym stopniowo zwiększał się udział kobiet $\mathrm{w}$ życiu społecznym i kulturalnym ${ }^{24}$. Kobiety z tej generacji: „po raz pierwszy w historii polskiej obyczajowości (...) podejmowały się ról zarezerwowanych dla płci przeciwnej; pracowały nad swoim wykształceniem, oddawały się pracy literackiej, nauczycielskiej, publicystycznej, politycznej, naukowej"25.

Spośród wymienionych uczennic Hoffmanowej to właśnie Żmichowska stała się jedną z czołowych animatorek ówczesnego ruchu emancypacji kobiet ${ }^{26}$. Wokół niej (oraz „Przeglądu Naukowego”) w latach czterdziestych XIX stulecia skupiło się grono nazwane później „Entuzjastkami”27, którego najważniejszymi celami programowymi były: praca wśród ludu i emancypacja kobiet ${ }^{28}$.

Aktywność Klementyny z Tańskich Hoffmanowej (na gruncie polskim) przypadła na czasy Królestwa Polskiego ${ }^{29}$. Za podstawowy cel swojej epoki oraz za własne posłannictwo społeczne i moralne

23 Por. S. Kieniewicz, Historia Polski 1795-1918, Warszawa 1980, s. 298, s. 298 i n.; J. Buszko, Wielka historia Polski: od niewoli do niepodlegtości (1864-1918), t. 8, Kraków 2000, s. 11 i n.

24 I. Ihnatowicz, A. Mączak, B. Zientara, J. Żarnowski, Spoteczeństwo polskie od $X$ do XX wieku, Warszawa 1996, s. 459.

25 G. Borkowska, Cudzoziemki. Studia o polskiej prozie kobiecej, wyd. cyt., s. 66.

26 M. Woźniakiewicz-Dziadosz, hasło: Emancypacja kobiet, w: Stownik literatury polskiej XIX wieku, red. J. Bachórz, A. Kowalczykowa, Wrocław 2002, s. 225-231.

27 M. Romankówna, Sprawa Entuzjastek, „Pamiętnik Literacki” (48) 1957, z. 2, s. 517-537.

28 J. Bachórz, hasło: „Entuzjastki i Entuzjaści”, w: Stownik literatury polskiej XIX wieku, dz. cyt., s. 232.

29 Po klęsce powstania listopadowego Tańska udała się na emigrację gdzie pozostała aż do swojej śmierci. Nazywaną ją „Matką Wielkiej Emigracji”. 
Tańska uznała zreformowanie wychowania i wykształcenia ówczesnych kobiet. Czasy, w których Tańska zaczynała swoją aktywność literacką (czyli około roku 1820): „była to u nas najnieszczęśliwsza jeszcze chwila pod względem wychowania kobiecego. Uboższa szlachta po wsiach, mieszczaństwo, zaniedbywało je zupełnie. Nie rozwijano wcale u dziewcząt władz umysłowych, ani siły charakteru; oprócz zasad wiary najczęściej wpajanych jednostronnie i fanatycznie, i praktycznego obeznania się z zajęciami domowemi, wychowanie nie przyniosło nic. Pomiędzy możniejszymi było ono gorzej niż zaniedbane, bo skrzywione i wynarodowione (...)" - pisała Felicja Boberska $\mathrm{z}$ domu Wasilewska ${ }^{30}$. Jedną z instytucji gdzie Tańska propagowała swój program wychowawczo-edukacyjny dziewcząt, był warszawski Instytut Rządowy Wychowania Płci Żeńskiej oraz związana z nim Pensja Wzorowa ${ }^{31}$.

Klementyna Tańska wykładała tam (nieodpłatnie) naukę moralną obyczajową (w 1 i 2 klasie po jednej godzinie tygodniowo), ówcześnie uważaną za jeden z przedmiotów głównych. Nauka moralności i obyczajów była bowiem istotnym narzędziem kształtowania osobowości dziewcząt, zgodnie z obowiązującym modelem obyczajowo-moralnym, opierającym się na wychowaniu religijnym. Artykuł 17 Urzadzenia Instytutu Rzadowego Wychowania Ptci Żeńskiej (z 22 listopada 1826) oprócz religii i moralności przewidywał dodatkowo „kurs osobnej moralnej nauki do płci żeńskiej szczególnie zastosowany", który miała prowadzić Dama Dozoru ${ }^{32}$. Celem wspomnianego kursu miało być „bliższe przygotowanie uczennic do przyszłego ich powołania, przez wykład powinności, płeć żeńską szczególniej obowiązujących i z przeznaczenia jej wynikających cnót i przymiotów, które w towarzystwie ludzkiem i w pożyciu domowem niewiastę

30 F. Wasilewska [Boberska], Klementyna z Tańskich Hofmanowa: odczyt Felicji Wasilewskiej z dnia 23 kwietnia 1871, Lwów 1871, s. 19.

31 Od strony historycznej temat Instytutu Guwernantek podejmowali: A. Winiarz, Szkolnictwo Księstwa Warszarwskiego o Królestwa Polskiego (1807-1831), Lublin 2002, s. 328-335 oraz J.E. Dąbrowska, Początki szkolnictwa żenskiego - Instytut Guwernantek, w: Z dziejów polskiej kultury i oświaty od średniowiecza do początków XX wieku, red. K. Jakubiak, T. Maliszewski, Kraków 2010, s. 119-132.

32 Urzadzenie Instytutu Rzaqdowego Wychowania Ptci Żenskiej, w: Zbiór przepisów administracyjnych Królestwa Polskiego. Wydziat Oświecenia, t. 5: Zaktady naukowe średnie, dz. cyt., s. 365, art. 17. 
dobrze wychowaną szczególnie odznaczać mają oraz wad, których troskliwie unikać należy" ${ }^{\prime 3}$.

Jako że podstawowym zadaniem Instytutu Guwernantek było wykształcenie przyszłych nauczycielek, $\mathrm{w}$ trzecim roku nauki umożliwiono dziewczętom odbywanie praktyk (kosztem znacznego zmniejszenia liczby godzin lekcyjnych - do pięciu tygodniowo). Początkowo praktykowały one w formie korepetycji, jednak w lipcu 1828 roku w tym celu przemianowano pensję Zuzanny Wilczyńskiej na placówkę ćwiczeń i zatwierdzono ją jako Pensję Wzorową przy Instytucie Guwernantek.

Chociaż Klementyna z Tańskich Hoffmanowa nie stworzyła systemu pedagogicznego, to jednak zdołała narzucić opinii publicznej ,jasno sprecyzowany ideał wychowawczy kobiet oraz program naukowy"34. Jej poglądy na wychowanie dziewcząt, będące wyrazem przemyślanego i konsekwentnego stanowiska $\mathrm{w}$ sprawach edukacyjnych, znalazły odbicie w licznych utworach literackich autorki na czele z powieścią Pamiątka po dobrej matce czyli ostatnie jej rady dla córki, której pierwsze warszawskie wydanie $(1819)^{35}$ przyjęto „z najwyższym aplauzem”36. Powieść ta, inspirowana dziełem Jakuba Glatza (Rosaliens Vermächtniss an ihre Tochter Amanda, 1809) oraz traktatami francuskimi (m.in. Fénelona, Mme de Lambert, Rousseau) przyniosła młodej autorce rozgłos i szacunek społeczny. Komisja Rządowa Wychowania Religijnego i Oświecenia Publicznego zaliczyła wspomniany utwór w poczet książek przeznaczonych do użytku pensji i szkół żeńskich. W ten sposób w XIX stuleciu powieść Tańskiej stała się istotnym narzędziem pedagogicznym. Zawarty w Pamiatce po dobrej matce program wychowania dziewcząt był rozwijany (i nieznacznie modyfikowany) w kolejnych utworach Klementyny z Tańskich Hoffmanowej, m.in. w Listach matki

33 Tamże, s. 371-373, art. 24

34 J. Hulewicz, Sprawa wyższego wyksztatcenia kobiet w Polsce w wieku XIX, dz. cyt., s. 36 .

35 Pamiątka miała wiele wydań, do 1940 roku - 16, tłumaczono ją na języki: rosyjski, francuski, czeski. Powieść inspirowała utwór czeskiej autorki polskiego pochodzenia Honoraty z Wiśniewskich Zapovej Niezapominajki, dar dla naszych panien (1849).

36 A. Kowalska, Warszawa literacka wokresie przetomu kulturalnego 1815-1822, Warszawa 1961, s. 171. 
o wychowaniu córek swoich (ogłoszonych „Rozrywkach dla Dzieci” 1824-1826), w powieści Amelia matka. Dzieto za dalszy ciag "Pamiątki po dobrej matce" stużyć mogqee, przez tę̇ं sama Autorkę (Warszawa 1822-1822, t. 1-3), a przede wszystkim w wydanej kilka lat po śmierci autorki rozprawie $O$ powinnościach kobiet (Berlin 1849) stanowiącej rozszerzoną wersją wykładów z czasów pracy autorki w Instytucie Guwernantek ${ }^{37}$.

W czasach aktywności Klementyny Tańskiej sytuacja kobiety na ziemiach polskich nie była łatwa - zależała ona przede wszystkim od uregulowań prawnych, funkcjonujących w każdym z państw zaborczych $^{38}$. Istniały jednak pewne cechy wspólne ustawodawstwa odnoszącego się do kobiet. We wszystkich trzech państwach kobiety nie posiadały praw wyborczych (przez cały wiek XIX) nie miały też jednakowych z mężczyznami praw dysponowania majątkiem. Szczególnie w chwili zawarcia małżeństwa prawa majątkowe kobiet ulegały ograniczeniu na rzecz męża ${ }^{39}$. Przy tym z drugiej strony od czasu tragicznego roku $1795 \mathrm{w}$ warunkach niewoli politycznej, to właśnie polskie kobiety (matki) i polskie domy, stały się rodzajem „instytucji kontynuującej i rozwijającej kulturę polską", jeśli ta miała przetrwać zabory $^{40}$. Kilka lat po trzecim rozbiorze Rzeczypospolitej Julian Ursyn Niemcewicz zalecał swoim rodakom, aby przede wszystkim „pełnili cnoty domowe”, podkreślając, że to „matki przypominają dzieciom, że miały ojczyznę"41. Życiowym celem Tańskiej stało się właśnie wychowanie strażniczek takich rodzin ${ }^{42}$.

37 W roku 1840 wydała Tańska ich skróconą (przerobioną) wersję pt. O moralności kobiet przez Klementynę z Tańskich Hoffmanowq w poznańskim „Dzienniku Domowym” (1840). Poszczególne fragmenty ukazywały się w różnych numerach pisma przez cały rok 1840.

38 Por. R. Bednarz-Grzybek, Emancypantka i patriotka: wizerunek kobiety przetomu XIX i XX wieku w czasopismach Królestwa Polskiego, Lublin 2010, s. 25.

39 Por. M. Bogucka, Gorsza pteć. Kobieta w dziejach Europy od antyku po wiek XXI, Warszawa 2005, s. 243; M. Pietrzak, Sytuacja prawna kobiet w Drugiej Rzeczypospolitej, w: Kobieta i świat polityki w niepodlegtej Polsce 1918-1939, red. A. Żarnowska, A. Szwarc, Warszawa 1996, s. 38-40.

40 Por. J. Prokop, Universum polskie. Literatura, wyobraźnia zbiorowa, mity polityczne, Kraków 1993, s. 26.

41 J.U. Niemcewicz, Wstepp, w: Dzieta, Warszawa 1803, s. 5.

42 K. Hoffmanowa z Tańskich, O powinnościach kobiet, w: Dzieła, red. N. Żmichowska, t. 9, Warszawa 1876, s. 407; Taż, Pamiatka po dobrej matce, dz. cyt., s. 78. 
Mając na względzie ów cel nadrzędny, Tańska eksponowała w swoich kolejnych utworach konieczność trzymania się przez mężczyzn i kobiety swoich ról, uzasadniając to odwiecznym porządkiem świata: „każdy winien być tem, czem się urodził” - pisała ${ }^{43}$. Zaś pojawiające się wśród jej współczesnych głosy namawiające do zmian w tym względzie nazwała jednoznacznie, ,niedorzecznością”, zalecając kobietom trzymanie się „ściśle i chętnie części wydzielonej nam przez Boga" ${ }^{\prime 4}$. To właśnie argumentacja religijna stała się podstawą „nauki moralnej” i poglądów Tańskiej na rolę mężczyzn i kobiet $\mathrm{w}$ społeczeństwie. Warto zwrócić uwagę, że poglądy Tańskiej na kobiety zawarte w Pamiątce po dobrej matce miały także swoje źródło w protestanckiej - mieszczańskiej myśli zachodnioeuropejskiej. Wszak, jak wspomniano, powieść Tańskiej posiadała swój niemiecki pierwowzór.

Swoim czytelniczkom i uczennicom przypominała Tańska, że „mężczyzn Stwórca do rządzenia i starszeństwa przeznaczył”, zaś kobiety do „uległości” i do „posłuszeństwa”45. Dlatego zalecała dziewczętom: „ulegaj ojcu, mężowi, starszym, czyń ich wolę”46, „cierpliwość, słodycz, uleganie, jednostajność humoru nieodzownie potrzebne są każdej kobiecie"47. Autorka Pamiątki po dobrej matce propagowała ideał kobiety pokornej, delikatnej, skromnej, łagodnej, czułej: „Bóg stworzył kobietę: łagodzić, miękczyć, uszczęśliwiać śmiałego towarzysza” - pisała ${ }^{48}$. Co istotne, miała to być również kobieta aktywna, pracująca, potrafiąca w razie potrzeby, utrzymać siebie i bliskich ${ }^{49}$. Podobnie jak wcześniej Jean-Jacques Rousseau (w Emilu) twierdziła Tańska, że kobieta i mężczyzna nie powinni mieć tego samego wychowania: zaś zasadą wychowania kobiety musi być rola, jaką ma ona spełnić w życiu mężczyzny.

Współcześnie bardzo łatwo ulec pokusie krytyki Tańskiej i upowszechnianych przez nią wzorców. Na jej poglądy należy zaś patrzeć

43 K. Hoffmanowa z Tańskich, O powinnościach kobiet, dz. cyt., s. 406.

44 Taż, Pamiątka po dobrej matce, dz. cyt., s. 25.

45 Tamże, s. 18.

46 Tamże, s. 105.

47 Tamże, s. 195.

48 K. Hoffmanowa z Tańskich, Pamiątka po dobrej matce, dz. cyt., s. 7-8.

49 Taż, O powinnościach kobiet, dz. cyt., s. 152; Pamiatka po dobrej matce, dz. cyt., s. $46-47$. 
w perspektywie historycznej. Propagując tradycyjny wzór kobiecości, mocno oparty na wartościach religijnych („nie można być szczęśliwym bez religii i pobożności”50), Tańska starała się bowiem stworzyć bazę pozwalającą zachować ład społeczny oraz oparcie dla polskich rodzin czasów niewoli. Bo to właśnie w rodzinie pisarka widziała ostoję tożsamości narodowej - i temu nadrzędnemu celowi podporządkowała nawet wolność indywidualną polskich kobiet.

Klementyna z Tańskich Hoffmanowa przekonywała również, że chociaż kobieta została „przeznaczona do rzędu drugiego" ${ }^{51}$, to jednak ma ona do spełnienia ważną rolę, bo to w jej ręce „złożone zostaty (...) zarzewia wiary, cnót domowych i obywatelskich"52. Przy tym, chociaż Hoffmanowa podkreślała „obywatelskość” kobiet ${ }^{53}$, wyznaczając im szereg powinności (m.in.: podtrzymywanie tożsamości narodowej, nauczanie ubogich, miłosierdzie, filantropię), to jednak nie godziła się, aby aktywnie włączały się one do polityki, czy zajmowały „wysoką nauką". W Pamiatce po dobrej matce jej autorka pisała: „Nigdy nie chwalę kobiety, kiedy się oddaje wysokim naukom, kiedy się uczy łacińskiego, greckiego, hebrajskiego języka, doświadczenia robi w fizyce, chemii i nad algebrą lub matematyką głowę sobie łamie"54.

Również w Instytucie Guwernantek nauczyciele zostali zobowiązani określonymi przepisami do przekazywania uczennicom jedynie wiadomości podstawowych. W przepisach Urządzenia Instytutu Rzqdowego Wychowania Ptci Żeńskiej podkreślano: „Nauczyciele w wykładzie nauk (...) nie będą się zapuszczać w głębokie badania, w rozwijanie w całej obszerności zasad każdej nauki, bo to przechodzi powołanie kobiet (...). Obowiązkiem będzie nauczycieli zaszczepić i umocnić uczucie skromności i wstrzemięźliwości naukowej”55. Podobne zalecenia powtarzały się raz po raz w stosunku do poszczególnych przedmiotów (arytmetyki geografii, fizyki, chemii) ${ }^{56}$. Postanowiono, że jedynie roboty ręczne (m.in. krój i szycie bielizny 
oraz sukien) „mają być uważane i uczone w jak najobszerniejszym zakresie", podkreślano w artykule $34^{57}$. Hołdując tego rodzaju przekonaniom w rozprawie $O$ powinnościach kobiet Hoffmanowa pytała: „Co byśmy pomyśleli o niewieście, która by np. spór religijny w towarzystwie wiodła, tonem doktorskim trudne wykładała miejsca (...)? W całym układzie kobiety konieczną jest wstrzymałość" ${ }^{\prime 2}$.

Klementyna $z$ Tańskich Hoffmanowa była prekursorką i propagatorką kształcenia kobiet, przy tym jednak, jej zdaniem, ich wykształcenie musiało posiadać walor użyteczności. Zresztą, podobną tendencję posiadała cała pedagogika postanisławowska. Wobec swoich młodych słuchaczek Tańska nieraz podkreślała wartość wiedzy, ale przede wszystkim tej zgodnej $\mathrm{z}$ podstawowym przeznaczeniem kobiet, czyli „użytecznej” („Każdej nauki celem powinna być użyteczność”59) i „nie nazbyt głębokiej”: „Niech się nie uczy rzeczy niepożytecznych i błahych, równie jednak zbyt na jej umysł głębokich i niedostępnych (...) przeto nic bardziej zdrowiu nie szkodzi jak dumania nad rzeczą, której nie rozumie, jak klecenie słów w przedmiocie, któregośmy nie pojęły: taka praca zdaje się, że mózg suszy i przewraca" ${ }^{\prime 0}$.

W przekonaniu Tańskiej kształcenie kobiet miało obejmować obok podstawowych wiadomości naukowych $\mathrm{z}$ różnych dziedzin, przede wszystkim ściśle określone umiejętności (szycie, krój, haft, roboty domowe, prowadzenie domu i gospodarstwa). Tańska zwracała uwagę, że pozwolą one kobiecie, w razie przeciwności losu, własną pracą utrzymać siebie i bliskich: „Z rąk pracy utrzymać się można: a wszędzie (...) pokupniejsze hafty i szycia, jak niedoskonały rysunek lub nuty (...) Żyjemy w czasach, gdzie największe odmiany nie wydają się nadzwyczajne"61. W tym kontekście mogą dziwić zarzuty stawiane jej po latach przez Żmichowską, która oskarżała swoją dawną nauczycielkę o to, że „nie obmyśliła nic dla tych, co same przez świat iść będą musiały, same bez ojca, bez brata, bez męża (...”’².

\footnotetext{
$57 \quad$ Tamże, s. 381.

58 K. z Tańskich Hoffmanowa, O powinnościach kobiet, dz. cyt., s. 410.

59 Tamże, s. 189.

60 Tamże, s. 153.

61 K. z Tańskich Hoffmanowa, Pamiątka po dobrej matce, dz. cyt., s. 46-47.

62 N. Żmichowska, Stowo przedwstępne, dz. cyt.
} 
Wypowiadając się na temat edukacji kobiet, Klementyna z Tańskich Hoffmanowa zwracała uwagę na istnienie określonej grupy nauk, którymi mogą one zajmować się (oczywiście w stopniu umiarkowanym) bez większej szkody dla nich samych: „Kobieta tych nauk nabywać może i powinna, które duszę karmią, które nam przez serce przejść mogą (...). Jest dość nauk zupełnie zgodnych z powołaniem naszem. (...) Do ich rzędu liczę religię, moralność na religii opartą, czyli filozofię kobiet, znajomość ile można jak najobszerniejszą cudów i dziwów przyrodzenia [tzn. historii naturalnej - M.S.K.], w którą wejdzie lekkie wyobrażenie astronomii, fizyki i chemii; historią (...) wiadomości o ziemi całej, wiadomości dokładne dziejów swego kraju, zupełne posiadanie własnego języka, jednego lub dwóch obcych; znajomość prawdziwie pięknych twórców piśmiennictwa, a z dokładnych, czyli ze ścisłych umiejętności jedyną arytmetykę (...) Gdyby każda z nas nabyć ich chciała, nie zawróciłyby żadnej głowy, nie zaszkodziły zdrowiu, nie położyły tamy do spełnienia obowiązków płci naszej”33.

Według Klementyny z Tańskich Hoffmanowej podstawowym celem kobiet było „życie domowe” - małżeństwo i macierzyństwo (,życie domowe jest to zawód cały jaki Wszechmocny przeznaczył kobiecie" ${ }^{64}$ ). „Jak okropnie błądzi kobieta, która chce być nad to, co ją Bóg przeznaczył" - pisała w Pamiatce po dobrej matce $e^{65}$. Zgodnie z przekonaniem o podstawowym przeznaczeniu kobiet oraz celu ich edukacji i wychowania, w swoich pismach i wykładach wiele uwagi poświeciła małżeństwu („Małżeństwo jest wszystkiem dla kobiety, połową tego wszystkiego dla mężczyzny"), dając swoim czytelniczkom praktyczne rady w tym względzie (m.in. jak utrzymać zainteresowanie i miłość męża) ${ }^{66}$. Żywotności i aktualności ideałów propagowanych przez Tańską-Hoffmanową wśród społeczeństwa polskiego drugiej połowy XIX wieku dowodzą ówczesne zapiski pamiętnikarskie. Wśród nich znajdują się wspomnienia młodej Heleny

63 Tamże, s. 190-191.

64 K. Hoffmanowa z Tańskich, Pamiątka po dobrej matce, dz. cyt., s. 43.

65 Tamże, s. 9.

66 Tamże, s. 365 i n. W wieku XIX pojawiały się rozmaite poradniki dla panien i mężatek. Na ten temat pisała M. Stawiak-Ososińska, Ponętna, uległa, akuratna... Ideat $i$ wizerunek kobiety polskiej pierwszej potowy XIX wieku (w sivietle ówczesnych poradników), Kraków 2010. 
z Kadłubowskich Kunachowiczowej (ur. 1838), która w 1860 roku czyniła wobec poślubionego z rozsądku męża następujące postanowienie: „(...) to sobie dzisiaj przysięgam, że jakakolwiek przyszłość ma będzie, jaki dla mnie będzie mój mąż, którego zaledwie ośm razy widząc przed ślubem i znać nie mogę, to ja ze swojej strony dołożę wszelkich starań, aby stać się taką żoną, jaką Hoffmanowa w swych pamiętnikach przedstawiała" ${ }^{\prime 7}$.

\section{Oceny uczennic}

\section{Narcyza Żmichowska}

Jak wspomniano, ideał wychowawczy Tańskiej i propagowany przez nią wzorzec kobiecości został poddany surowej krytyce przez jedną z jej uczennic - Narcyzę Żmichowską. Obydwie pisarki dzieliło pokolenie - Żmichowska przyszła na świat w roku (1819), w którym Tańska wydała Pamiątke po dobrej matce. Przy tym różniły je doświadczenia generacyjne i życiowe, preferencje społeczno-kulturowe, temperament literacki, wreszcie poglądy na rolę i wychowanie kobiet. Nie godząc się z modelem kobiety propagowanym przez Tańską, po latach Narcyza Żmichowska zarzuciła jej patrzenie na kobiety przede wszystkim z męskiej perspektywy.

Poglądy Narcyzy Żmichowskiej ukształtowały się w opozycji do przekonań dawnej nauczycielki. „Zmieniły się okoliczności i usposobienie kobiet się zmieniło" - pisała w połowie lat siedemdziesiątych XIX stulecia Żmichowska, uznając ideały propagowane przez Hoffmanową za anachroniczne i nieadekwatne dla współczesnych jej czasów $w^{68}:$ „... jej przepisy nie wystarczają na zaspokojenie twardych wymagań dzisiejszej współczesności (...) Ze wszystkich stron już nowe teorie, nowe ideały, potrzeby nowe przeciskają się do nas rozmaitymi tytułami: emancypacji, równouprawnienia, wolności

67 H. z Kadłubowskich Kunachowiczowa, Dziennik z lat 1856-1860, w: Kapitan i dwie panny krakowskie pamiętniki z dziewiętnastego wieku, red. B. Łopuszański, I. Homola, Kraków 1980, s. 302.

68 N. Żmichowska, Stowo przedwstępne do dziet dydaktycznych pani Hoffmanowej, dz. cyt., s. 226. 
kobiet" ${ }^{69}$. Dawna uczennica - emancypantka - odrzuciła konserwatywny ${ }^{70}$ model kobiecości eksponowany przez swoją nauczycielkę, zastępując go modelem kobiety nowoczesnej i niezależnej.

Lista zarzutów byłej uczennicy wobec dawnej nauczycielki jest długa. W Stowie przedwstepnym do dziet dydaktycznych pani Hoffmanowej Żmichowska oskarżyła Tańską o koniunkturalizm, swoiste pisanie „pod publicznośc”, przekonując, że program wychowawczy propagowany przez Tańską ,zlewał się z krążącymi dokoła upodobaniami”" zaś jej piórem „pochlebstwo prowadziło”72. Idąc tym tropem Żmichowska przekonywała, że również tak gorliwe propagowanie religii przez jej nauczycielkę wynikało nie tyle z przekonania społecznego, co przede wszystkim było wyrazem swoistej „pogoni za modą: skoro „religia [była] w modzie, ona się do religii dzieła wzięła" - pisała uczennica Tańskiej, jakby zapominając, że owa rzekoma „moda” na religijność na gruncie polskim miała już przeszło tysiąc $\mathrm{lat}^{73}$.

Otwartym pozostaje natomiast pytanie, czy (i w jakim stopniu) propagowane przez Tańską poglądy na kobiety oraz ich rolę były bliskie jej samej? Tego rodzaju pytanie wcale nie jest bezzasadne. Biorąc bowiem pod uwagę wzorce kobiecości upowszechniane w twórczości Tańskiej oraz jej własną aktywność zawodową, można odnieść wrażenie (takie, jakie miała Żmichowska) pewnego rozdźwięku pomiędzy teorią propagowaną przez Tańską a praktyką jej życia zawodowego (aktywność, samodzielność, niezależność, realizacja zawodowa). Żmichowska dostrzegała w tym przede wszystkim „obłudę” swojej dawnej nauczycielki - co innego odnoszącej do siebie samej, a co innego nakazującej pozostałym kobietom. Pozostawiając na boku motywacje Żmichowskiej, warto zwrócić uwagę, że rozpowszechnianie przez Tańską wśród ówczesnego społeczeństwa polskiego ściśle określonego ideału wychowawczego kobiety było prawdopodobnie nie

69 Tamże, s. 208-209.

70 Tego terminu użyto tutaj w znaczeniu najściślejszym (jak E. Burke), oznaczającym budowanie na fundamentach tradycji, ale także przyjmowanie do wiadomości istotnych rezultatów przemian historycznych.

71 N. Żmichowska, Stowo przedwstęne do dziet dydaktycznych pani Hoffmanowej, dz. cyt., s. 239.

72 Tamże, s. 263.

73 Tamże, s. 263. 
tyle efektem jej osobistych preferencji (o czym świadczy jej własne życie), ile raczej świadomym wyborem dokonanym w perspektywie społecznej. Decyzją zdeterminowaną przekonaniem, że w aktualnych realiach historycznych (upadek Rzeczypospolitej, zabory, załamanie nadziei związanych z Napoleonem, władza cara) właśnie tego rodzaju wzorce są Polsce niezbędne.

Nie rozumiejąc intencji Tańskiej, Żmichowska na kartach swojej rozprawy nie oszczędzała poczytnej Pamiątki po dobrej matce. Zawarte tam wskazówki określiła mianem „komunałów”, „pospolitości”74, zwracając przy tym uwagę, że autorka zgromadziła w swojej powieści „wszystkie ogólniki od czasów niepamiętnych rozpowszechniane i uznane"75. Długą listę oskarżeń Żmichowskiej wobec Tańskiej dopełniają te o zdradę ideałów, które to pisarka (przyjmując na siebie bezpieczną rolę moralistki propagującej wartości tradycyjne, akceptowane społeczne) miała, zdaniem dawnej uczennicy, zamienić ma „sutą płacę” oraz „Zapewniony fundusz”. „Spadła na nią kilkutysięczna gratyfikacja (...) później nawet i owa upragniona pensja dożywotnia jej nie minęła" - pisała Żmichowska ${ }^{76}$.

Ogromną popularność dzieł Tańskiej wydawanych w latach dwudziestych i trzydziestych XIX wieku oraz propagowanego przez pisarkę wzorca wychowawczo-edukacyjnego kobiet Żmichowska tłumaczyła w swoisty sposób: „Bardzo maluczkie rzeczy bardzo wielką na siebie zwracały uwagę, dostarczały przedmiotu do rozpraw najwykwintniejszym salonom stolicy, ważyły szalę powodzenia pism periodycznych"77. Dwie dekady temu Grażyna Borkowska w książce Cudzoziemki. Studia o polskiej prozie kobiecej, przytaczając powyższy cytat z pism Żmichowskiej, dodała: „W latach dwudziestych i trzydziestych poziom życia literackiego i naukowego na ziemiach

74 Tamże, s. 216.

75 Tamże, s. 219.

76 Tamże, s. 263. W 1827 roku na wniosek Dozoru pensji i szkół płci żeńskiej w nagrodę zasług literackich, pełnienia obowiązków dozorczyni i bezpłatnego pełnienia obowiązków nauczycielki w Instytucie Rządowym Guwernantek, Komisja Rządowa Wyznań Religijnych i Oświecenia Publicznego przyznała Tańskiej dożywotnią pensję w wysokości 6000 złp rocznie. Co zresztą było ówcześnie kwotą niebagatelną, jeśli zestawi się ją choćby z najwyższą pensją, jaką mógł zarobić nauczyciel w Instytucie Rządowym Guwernantek - $1200 \mathrm{zlp}$.

77 Tamże, s. 292. 
polskich był niski. (...) Debiut Hoffmanowej nastąpił w okresie kompletnej posuchy intelektualnej, odbił się zatem większym echem niż

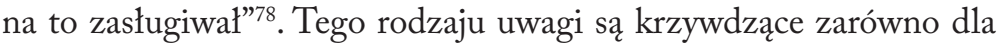
samej Tańskiej jak i czasów, w których wydawała swoje dzieła. Lata dwudzieste i trzydzieste XIX wieku to przecież czas wielkiej przemiany oświeceniowo-romantycznej. W tym okresie miał miejsce znaczny ruch intelektualny - zarówno na prowincji (głównie w Wilnie) jak i w samej Warszawie, potem zaś na emigracji ${ }^{79}$. Przyczyna ówczesnej popularności dzieł i programu wychowawczego Tańskiej leżała zupełnie gdzie indziej. Autorka Pamiatki po dobrej matce trafiła bowiem swoim dziełem w potrzeby i oczekiwania jej współczesnych ${ }^{80}$. Nie bez znaczenia był też fakt, że Tańska potrafiła „przemówić do ogółu” złożonego „przeważnie z umysłów średniej zdolności, który (...) nauki gruntownej i głębokiej nie potrzebował; uczucia bardzo łatwo zaspokajał" - jak pisał przed laty Piotr Chmielowski ${ }^{81}$.

Podsumowując rady Tańskiej na osiągnięcie szczęścia rodzinnego, Żmichowska określiła je jako „złudną fata morganę". Zarzucając poglądom Hoffmanowej jednostronność w pojmowaniu kobiet i ich roli, sama była dość jednostronna. Poddała bowiem wzorce stworzone przez jej dawną nauczycielkę ocenie tylko z jednej perspektywy z punktu widzenia emancypantki drugiej połowy XIX wieku, dla której indywidualna wolność kobiety była wartością nadrzędną.

Seweryna Duchińska z domu Żochowska $1^{\circ}$ v.

Pruszakowa, Teodozja Papiz domu Gałezowska

Osądy Żmichowskiej wobec Tańskiej często rozmijają się z ocenami wystawionymi dawnej nauczycielce przez inne jej uczennice: Sewerynę Duchińską z domu Żochowską $1^{\circ}$ v. Pruszakową oraz Teodozję Papi z domu Gałęzowską. Przykładowo, kiedy Żmichowska

78 G. Borkowska, Cudzoziemki. Studia o polskiej prozie kobiecej, dz. cyt., s. 64.

79 Zob. m.in.: M. Stanisz, Wczesnoromantyczne spory o poezje, Kraków 1998; A. Kowalska, Warszawa literacka w okresie przetomu kulturalnego 1815-1822, Warszawa 1961.

80 Odczyt Felicji Wasilewskiej, w: F. Wasilewska [Boberska], Pisma, Lwów 1893, s. 3-4.

81 P. Chmielowski, Klementyna z Tañskich Hoffmanowa. Zarys biograficzno-pedagogiczny, dz. cyt., s. 11, 56. 
eksponowała, jej zdaniem, niewłaściwe podejście Tańskiej do swoich uczennic, zarzucając jej rzekome faworyzowanie tych lepiej urodzonych i ładniejszych, Pruszakowa miała na ten temat odmienne zdanie. Żmichowska w swoim Stowie przedwustępnym do dziet dydaktycznych Pani Hoffmanowej pisała: „Pani H. ani zdolnością, ani pilnością ująć się nie dała nigdy; jej zachowanie się względem «instytutek» było zawsze bardzo chłodne (...) arystokratyczne (...). Niejedna, która pierwej zachwycając się Pamiątka i „Rozrywkami” wzdychała do poznania pani H., siadłszy potem w ławce, w rzędzie jej słuchaczek, wydziwić się nie mogła, czemu tak przyjemna powierzchowność, tak śliczne czytanie rzeczy, głębszego na niej nie czyniły wrażenia (...) Jej naukom brakło ożywczego ciepła i przenikającej głąb duszy skuteczności. (...) Nie wytworzyła ze swego audytorium licznego zastępu dość gorliwych zwolenniczek (...) Spotkaliśmy w dalszem życiu wiele kobiet, na których drukowane dzieła p. H. stanowczy wpływ wywarły; nie spotkaliśmy uczennicy, która by z jej ustnego wykładu zaczerpnęła jaką pomoc w urządzeniu swego losu $(\ldots)^{82}$. Tymczasem Seweryna Pruszakowa dekadę od śmierci swojej nauczycielki, w życiorysie Hoffmanowej zamieszczonym na łamach „Rozrywek dla wieku młodocianego”, wspominała: „Znałam ją osobiście, przez dwa lata należałam do liczby jej uczennic, słuchałam z ust jej wykładu nauki obyczajowej, której udzielała z taką prostotą i namaszczeniem. Pierwsze zamiłowanie swojskich rzeczy i własnego języka, pismom jej winna jestem, wyłącznie. Po matce mojej, która nauczyła mnie pacierza i głównych zasad wiary świętej, Hoffmanowa najwięcej wpłynęła na rozwinięcie umysłu mego i rozbudzenie w sercu uczucia ku wszystkiemu co wzniosłe, piękne i uświęcone wspomnieniami. Ona też była drugą matką moją (...) dziesięć lat upłynęło od skonu Hoffmanowej, pamięć jej dotąd nie zatarła się w mojem sercu" ${ }^{\text {"3. }}$.

82 N. Żmichowska, Stowo przedwstepne do dziet dydaktycznych Pani Hoffmanowej, dz. cyt., s., 269-270.

83 S. Pruszakowa [Duchińska], Rozrywki dla wieku mtodocianego, Warszawa 1856, t. 1, s. 291-192. Inna uczennica Tańskiej z Instytutu Guwernantek, Emilia Filleborn późniejsza Stanczukowska (1814-1892), która przez dziesięć lat prowadziła w Kaliszu renomowaną pensję żeńską (1840-1850), chociaż nie pozostawiła wspomnień z tego okresu, to po latach, oddając część zasługom swojej nauczycielki, postarała się o wmurowanie tablicy poświęconej Tańskiej w kościele ojców franciszkanów w Kaliszu. 
Pełen autobiograficznych odniesień życiorys Hoffmanowej pióra Pruszakowej pozbawiony jest jakiejkolwiek krytyki w stosunku do dawnej nauczycielki. W przeciwieństwie do Żmichowskiej, Pruszakowa nie pozostawia nawet cienia wątpliwości co do oceny samej Hoffmanowej oraz jej programu wychowawczego.

Podobny obraz Hoffmanowej jako nauczycielki wyłania się z kart powstałej na początku XX stulecia powieści Jadwigi Papi Klementyna. Powieś́ dla dorastajacych panien osnuta na tle życia Klementyny z Tańskich Hoffmanowej. Autorka, chociaż sama osobiście nie znała Hoffmanowej, to jednak zainspirowana młodzieńczymi wspomnieniami swojej matki, Teodozji de domo Gałęzowskiej, dała literacki obraz prowadzonych przez nią lekcji oraz serdecznych relacji nauczycielki z uczennicami (w tym z jej małoletnią matką). Tym zdecydowanie pochlebnym wizerunkiem Tańskiej powieściopisarka starała się podtrzymywać na początku XX stulecia jej mit społeczny. Pisząc Klementynę, Jadwiga Papi stworzyła powieść z tezą, apoteozującą Hoffmanową: pokazała ją jako nauczycielkę idealną cieszącą się wśród uczennic podziwem i szacunkiem (za: „miłość do naszej literatury i naszego języka (...) do naszej przeszłości”). Dla powieściowej Klementyny nauczycielstwo było prawdziwym powołaniem: „Nie macie pojęcia, jaki to piękny i miły zawód nauczycielki” - mówiła bohaterka powieści Jadwigi Papi do swoich sióstr, przekonując je do licznych zalet tejże profesji ${ }^{84}$. Tymczasem realna Klementyna z Tańskich Hoffmanowa tuż po otrzymaniu informacji o powierzeniu jej wykładów zanotowała w swoim pamiętniku: „Dziś wezwaną zostałam na profesorkę do Instytutu Guwernantek, trudny to będzie kawałek"85. Zaś po latach, przebywając już na emigracji, wyznała, że choć wszystko straciła w powstaniu, to obecne jej położenie ma też swoje dobre strony: nie potrzebuje bowiem chodzić na lekcje ${ }^{86}$.

Zarówno biografia pióra Seweryny Pruszakowej gloryfikująca Klementynę z Tańskich Hoffmanową, jak i powieść Jadwigi Papi idealizująca ją oraz jej aktywność literacko-pedagogiczną, stanowią

84 J. Papi, Klementyna. Powieśc dla dorastających panien osnuta na tle życia Klementyny z Tanskich Hoffmanowej, dz. cyt., s. 271.

85 K. Hoffmanowa z Tańskich, Pamiętniki, t. 1, Berlin 1849, s. 130.

86 J.E. Dąbrowska, Klementyna. Rzecz o Klementynie z Tańskich Hoffmanowej, dz. cyt., s. 204. 
próbę zbudowania pośmiertnej legendy biograficznej autorki $P a-$ miatki po dobrej matce, mającej za zadanie utrwalenie jej dokonań w pamięci kolejnych pokoleń.

\section{Zakończenie}

Oprócz wspomnianych absolwentek Instytutu Rządowego Wychowania Płci Żeńskiej lub Pensji Wzorowej, Klementyna z Tańskich Hoffmanowa przez lata dochowała się licznego grona „uczennic duchowych" ${ }^{87}$ wywodzących się z kilku kolejnych porozbiorowych generacji kobiet, które dorastały kształtowane przez jej dzieła. Jedna z nich, Felicja Boberska z domu Wasilewska (18251889), blisko trzy dekady po śmierci Hoffmanowej napisała: „Wyrosłyśmy $\mathrm{z}$ jej pismami $\mathrm{w}$ ręku, $\mathrm{z}$ jej słowami $\mathrm{w}$ sercach i ustach. Jeżeli wychowanie nasze nie było lekkomyślne, powierzchowne, $\mathrm{cu}^{-}$ dzoziemskie, jeżeli uczono nas żyć dla powinności i prawdy, jeżeli pokochałyśmy wszystko dobre i szlachetne, zapragnęłyśmy światła i wiedzy, w znacznej części zawdzięczamy to Hoffmanowej (...)"88.

Chociaż spory o aktualność programu Klementyny z Tańskich Hoffmanowej i próby jego przewartościowania po upadku powstania styczniowego były z pewnością zasadne, to niewątpliwie jej zasługą pozostało, że jako pierwsza zaproponowała i rozpropagowała konsekwentny program wychowawczy dla polskich kobiet generacji porozbiorowych.

\section{BIBLIOGRAFIA}

Bogucka M., Gorsza pteć. Kobieta w dziejach Europy od antyku po wiek XXI, Wydawnictwo Trio, Warszawa 2005.

Borkowska G., Cudzoziemki. Studia o polskiej prozie kobiecej, Instytut Badań Literackich Polskiej Akademii Nauk, Warszawa 1996.

Chmielowski P., Klementyna z Tańskich Hofmanowa. Zarys biograficzno-pedagogiczny przez Piotra Chmielowskiego, K. Grendyszyński, Petersburg 1898.

87 Por. A. Pług, $Z$ powodu setnej rocznicy urodzin Hoffmanowej, „Kurier Warszawski” 1898, nr 324, s. 2.

88 F. Wasilewska [Boberska], Klementyna z Tanskich Hofmanowa: odczyt Felicji Wasilewskiej z dnia 23 kwietnia 1871, dz. cyt., s. 3-4. 
Ciechanowska Z., Hoffmanowa z Tańskich Klementyna (1798-1845), w: Polski Stownik Biograficzny, t. 9, Polska Akademia Nauk i Polska Akademia Umiejętności, 1961.

Dąbrowska J. E., Klementyna. Rzecz o Klementynie z Tanskich Hoffmanowej, Trans Humana, Białystok 2008.

Dąbrowska J.E., Początki szkolnictwa żeńskiego - Instytut Guwernantek, w: $Z$ dziejów polskiej kultury $i$ oświaty od średniowiecza do początków XX wieku, red. K. Jakubiak, T. Maliszewski, Oficyna Wydawnicza „Impuls”, Kraków 2010.

Hoffmanowa z Tańskich K., O powinnościach kobiet, w: Dzieła, red. N. Żmichowska, t. 9, Nakład: Spółka Wydawnicza Księgarzy, Warszawa 1876.

Hoffmanowa $z$ Tańskich K., Pamiatka po dobrej matce czyli ostatnie jej rady dla córki, Drukiem i nakładem Wilhelma Bogumiła Korna, Wrocław 1833.

Hoffmanowa z Tańskich K., Pamiętniki Klementyny z Tańskich Hoffmanowey, w: Pisma pośmiertne Klementyny z Tanskich Hoffmanowey, Berlin 1849 , t. 1.

Hulewicz J., Sprawa wyższego wyksztatcenia kobiet w Polsce w wieku XIX, nakładem Polskiej Akademii Umiejętności, Kraków1939.

Ilnicka M., M. Narcyza Żmichowska, „Bluszcz” 1877, nr 4-16.

Kotowa I., Pierwsze dzieto Klementyny Tańskiej, „Pamiętnik Literacki” 1925/1926, R. 22/23.

Nitowski J., Klementyna z Tańskich Hoffmanowa, „Przegląd Pedagogiczny” 1898, nr 23.

Papi J., Klementyna. Powieś́ dla dorastających panien osnuta na tle życia Klementyny z Tańskich Hoffmanowej, Warszawa-Kraków 1905.

Pług A., Z powodu setnej rocznicy urodzin Hoffmanowej, „Kurier Warszawski” 1898, nr 324.

[Pruszakowa S. Duchińska], Rozrywki dla mtodocianego wieku: dzieto zbiorowe w tomach 5 obejmujace powieści, podróże, literature i rozmaitości, Warszawa 1956, t. 1-2.

Regulament pensyj i szkót ptci żenskiej z dn. 9 III 1810, w: Źródta do dziejów wychowania i szkolnictwa w Polsce z doby Izby Edukacji Publicznej 1807-1812, zebr. Z. Kukulski, Towarzystwo Przyjaciół Nauk w Lublinie, Lublin 1931.

Romankówna M., Sprawa Entuzjastek, „Pamiętnik Literacki”(48) 1957, z. 27.

Romankówna, Narcyza Żmichowska (Gabriella), Polska Akademia Nauk. Oddział w Krakowie, Kraków1970.

Szczegótowa instrukcja względem sposobu dawania nauk po pensjach i szkotach wyższych ptci żeńskiej, Warszawa 1826.

Szulakiewicz W., Ego-dokumenty $i$ ich znaczenie w badaniach naukowych, „Przegląd Badań Edukacyjnych” 2013, nr 16.

Urządzenie Instytutu Rzq̨dowego Wychowania Ptci Żeńskiej (22 listopada 1826), w: Zbiór przepisów administracyjnych Królestwa Polskiego. Wydziat Oświecenia, Warszawa 1868, t. V. 
Winiarz A., Szkolnictwo Księstwa Warszarwskiego o Królestwa Polskiego (1807-1831), Wydawnictwo Uniwersytetu Marii Curie-Skłodowskiej, Lublin 2002.

Kobieta i edukacja na ziemiach polskich w XIX i XX wieku, red. A. Żarnowska i A. Szwarc, cz. 2, Instytut Historyczny UW, Warszawa 1995.

Woźniakiewicz-Dziadosz M., Dzieje przyjaźni entuzjastek w świetle listów Narcyzy Żmichowskiej do Bibianny Moraczerwskiej, Annales Universitatis Mariae Curie-Skłodowska, Lublin - Polonia, vol. XX/XXI, sectio FF, 2002/2003 (UMCS LUBLIN).

Żmichowska N., Stowo przedwstepne do dziet dydaktycznych pani Hofmanowej, w: Dzieta Klementyny z Tańskich Hofmanowej, t. 8, Spółka Wydawnicza Księgarzy, Warszawa 1876.

\section{ADRES DO KORESPONDENCJI}

Dr Monika Stankiewicz-Kopeć

Akademia Ignatianum w Krakowie,

Wydział Filozoficzny, Instytut Kulturoznawstwa

Katedra Dziedzictwa Kulturowego Polski

monika.kopec@ignatianum.edu.pl 